MAJ

25,2

182

Received 11 November 2008

Revised 4 August 2009

Accepted 18 August 2009

\section{Determinants of corporate internet reporting: evidence from Egypt}

\author{
Doaa Aly
}

Gloucestershire Business School, University of Gloucestershire, Cheltenham, UK

Jon Simon

Hull University Business School, University of Hull, Hull, UK, and

Khaled Hussainey

Accounting and Finance Division, Stirling Management School, University of Stirling, Stirling, UK

\begin{abstract}
Purpose - The purpose of this paper is to examine the potential factors that may affect the level of corporate internet reporting by Egyptian listed companies.

Design/methodology/approach - The content analysis approach to examine the information cited by the largest Egyptian companies is used in their web sites. The paper modifies and uses the disclosure index of Xiao et al. Ordinary least square multiple regression analysis is used to examine the determinants of the internet reporting.

Findings - It is found that 56 per cent of Egyptian companies report a significant portion of information on their web sites. In addition, the paper finds that some financial characteristics explain the variation in the degree of internet reporting between Egyptian listed companies. In particular, profitability, foreign listing and industrial type (communications and financial services) are the determinants of the amount and presentation formatting of information disclosed on Egyptian companies' web sites. However, other firm characterises, such as firm size, leverage, liquidity and auditor size, do not explain corporate internet reporting.

Practical implications - The research finding is essential as it assists in informing regulators about the characteristics of Egyptian companies that are, and are not, satisfying national and international investors' demand of updated/online information. It also assists current and potential stakeholders to know the drives of corporate internet reporting in Egypt. Consequently, they may further investigate and verify such reporting practices. In practice, online reporting can be used as an effective tool for improving stakeholders' decision-making process. Therefore, further research can be undertaken to examine the degree to which online reporting provides value-relevant information for stakeholders.

Originality/value - To the best of the knowledge, there is no study examining the potential drivers of internet corporate reporting practice in Egypt. This paper is the first to examine the potential factors affecting corporate internet reporting in Egypt. The disclosure index used is designed to be suitable for companies working in the Egyptian environment.
\end{abstract}

Keywords Disclosure, Internet, Online reporting, Developing countries, Egypt

Paper type Research paper

\section{Introduction}

Vol. 25 No. 2, 2010

pp. $182-202$

(C) Emerald Group Publishing Limited 0268-6902

The potential role of the internet, as a relatively new means of communicating information to the general public in developing countries, is to meet stakeholder demands for greater speed and volume of timely information, in better and more 
effective ways (Willis et al., 2003). The use of the internet enables information to be disseminated worldwide and thus facilitate the improved availability of financial information in particular, so encouraging investment.

The purpose of this paper is to investigate the potential factors that may affect the level of corporate internet reporting by Egyptian companies listed on the Egyptian Stock Exchange[1]. Egypt was selected to investigate corporate internet reporting for several reasons. First, there is a need for Egypt, as a developing country, to raise capital, attract foreign investment and promote the confidence and understanding of stakeholders (Nafie, 2001; Kamel and Hussein, 2001). Therefore, fairness, efficiency and transparency of financial information are among the major objectives of the Egyptian Stock Exchange. Companies have incentives to disseminate financial information online to reach a wider range of international as well as national investors. Second, in a recent study, Ragab and Omran (2006) examined the extent to which national and international investors in the Egyptian stock market perceive accounting information to be useful for valuing stocks. They found that accounting information is value-relevant information in the Egyptian stock market and argued that the Egyptian stock market "needs complementary information sources other than published accounting reports to become more informationally efficient" (p. 295). We believe that internet reporting is one of the most important sources of such information and potentially complements other published accounting in Egypt. Finally, there is evidence that the number of internet users in Egypt is dramatically increased (Kamel and Hussein, 2002) with 75 per cent of users from the business community (Mintz, 1998). This evidence suggests that there is increasing need/trend in Egypt by different stakeholders to seek information through the internet.

To the best of our knowledge, there is no study examining the potential drivers of the levels of corporate internet reporting in Egypt. Consequently, our paper is the first to explore this issue. It contributes to the limited literature on disclosure practices in developing countries in general and in Egypt in particular. Our paper is important as it helps in informing regulators about the characteristics of companies that are, and are not, satisfying national and international investors' demand of online information.

The remainder of the paper is organised as follows. The next section reviews the literature and describes the development of our research hypotheses. The following section describes the research methodology. The next section provides the descriptive analysis and the main findings. The penultimate section concludes, discusses the research limitation and provides lines for further research.

\section{Literature review and hypotheses development}

The majority of internet reporting studies are focused on US and European Union countries. These studies started in the USA (Louwers et al., 1996; Booker and Galbreath, 1997; Gowthorpe and Flynn, 1997). The studies then expanded to include various European countries. Examples include country-specific studies, the UK (Marston and Leow, 1998; Hussey and Sowinska, 1999; Craven and Marston, 1999), Sweden (Hedlin, 1999), Germany (Marston and Polei, 2004) and Spain (Larran and Giner, 2002). Another strand of research compares the internet reporting practice among different developed countries.

A number of studies examined the determinants of internet financial reporting in developed countries such as New Zealand (Oyeler et al., 2003; Fisher et al., 2004), Australia (Lodhia et al., 2004; Chan and Wickramasinghe, 2006), Canada (Trabelsi et al., 2004; Trabelsi, 2007) and Japan (Marston, 2003).

\section{Corporate internet reporting}

183 
MAJ

25,2

184

It is noticeable that most of the prior studies were undertaken for developed countries, especially the US and European countries. The number of factors that drive firms to use the internet reporting in these studies is not identical. These factors include firms characteristics (i.e. firm size, profitability, industry type, leverage and audit type) and corporate governance characteristics (i.e. ownership structure, board composition, board size and duality). However, the results are often mixed. In addition, the findings of these studies may not be generalisable to different countries at different stages of development, or with different business environments and cultures.

A few studies on the determinants of the internet reporting were conducted in developing countries such as Thailand (Davey and Homkajohn, 2004), Malaysia (Hamid, 2005), some Arab countries (Ismail, 2002; Al-Htaybat and Napier, 2006) and China (Xiao et al., 2004; Zhang et al., 2007). To date, however, no study examines the determinants of the internet reporting in Egypt.

In Egypt, a limited number of studies have been undertaken to examine internet reporting. However, researchers have only used descriptive analysis to offer a general overview of the current situation of internet reporting in Egypt (Mohamed, 2002; Metwali, 2003; AlDeesty, 2004). These studies focused on the existence of web sites for large, listed companies and whether these companies disclosed some type of financial information on their web sites. These studies do not make any attempt to explain why the level of online disclosure varies between Egyptian companies. To the best of our knowledge, there is no study - to date - that examines the association between the level of corporate online reporting and firm characteristics in Egypt[2]. Therefore, our paper adds to the literature by exploring the factors that might affect the Egyptian companies' decision to increase their disclosure levels on their web sites.

A number of explanatory studies examine the determinants of online reporting. Some researchers examined only one factor such as firm size (Allam and Lymer, 2003) or industry type (Hussainey and Al-Nodel, 2008). Other researchers examined two factors such as company size and capital ownership (Pirchegger and Wagenhofer, 1999) or company size and industry type (Craven and Marston, 1999). A few studies examined a greater number of factors, such as Xiao et al. (2004). In the present paper, we examine seven factors as potential drivers of the internet reporting in Egypt. These factors are: firm size, leverage, audit size, profitability, liquidity, industry type and foreign listing. Prior studies have employed several theories to explain why companies may use the internet reporting. Relevant theories include agency theory and signalling theory.

Agency theory uses management incentives to explain voluntarily disclosure. Watson et al. (2002) stated that managers have incentives to increase disclosure to convince shareholders that they are acting optimally because they know that shareholders seek to control their behaviour through bonding and monitoring activities. Therefore, one way of reducing agency costs is to increase the levels of corporate disclosure. Many disclosure studies have used agency theory to explain cross-sectional variation in voluntary disclosure practice (Ruland et al., 1990; Cooke, 1989, 1991, 1993).

Based on signalling theory, firms tries to adopt the same level of disclosure as other firms within the same industry do because if a firm does not keep-up with the same level of disclosure as others, it may be perceived by stakeholders that it is hiding bad news (Craven and Marston, 1999). Therefore, firms may use internet disclosure to keep pace with other firms in the same industry. Craven and Marston (1999, p. 323) stated that: 
The very use of the Internet might itself be a signal of high quality. It implies that the firm is modern and up-to-date with the latest technology rather than old fashioned and conservative.

It is also argued that managers of profitable firms increase the level of disclosure to signal to investors that the firm is profitable and to support their continuation and compensation (Oyeler et al., 2003, p. 36).

Our paper develops hypotheses concerning the association between the internet reporting and seven firm characteristics which potentially affect disclosure decisions of Egyptian companies. These characteristics are: firm's size, profitability, leverage, liquidity, sector type, auditor size and foreign listing.

\section{Firm's size}

Prior research has examined the association between the level of internet reporting and firm's size and finds a significant positive association (Xiao et al., 1996). Xiao et al. (1996, p. 218) explained this association as follows:

Large companies are more likely than small ones to use IT [Information Technology] to improve financial reporting to meet the greater demand for information.

Ashbaugh et al. (1999) noted that economies of scale suggest that large firms are more likely to post-financial reports on web sites. This is because larger firms usually have more products and more complex distribution networks, which require larger and more complex management information systems and databases for management control purposes. In addition, McKinnon and Dalimunthe (1993, p. 40) argued that "larger firms tend to attract more analysts' followings than smaller ones, and may therefore be subjected to greater demand by analysts for private information". Therefore, disclosure costs per pound of sales may be generally lower for larger firms (Oyeler et al., 2003). Based on these arguments, we hypothesise that:

H1. Large Egyptian firms are more likely to disclose more information on their web sites than small Egyptian firms.

\section{Profitability}

Signalling theory suggests that profitable companies have an incentive to disclose more information, to signal the firm's profitability to investors to support management continuation of their positions and levels of compensation (Oyeler et al., 2003), and to raise capital at the lowest price (Marston and Polei, 2004). Agency theory also suggests that managers of profitable companies have an incentive to disclose more information in order to boost their compensation (Abd El Salam, 1999).

Prior research has examined the association between profitability and the extent of disclosure; however, the results are mixed (Street and Gray, 2002). For example, Pirchegger and Wagenhofer (1999) found that profitability affects internet reporting of Austrian companies, but it does not affect that of German companies. Marston and Polei (2004) and Oyeler et al. (2003) found that profitability is not associated with internet reporting. Ismail (2002) found that profitability may increase the likelihood of the firm publishing financial information via the internet when this variable is within a particular range. If it increases beyond this range, the likelihood of firms publishing financial information on the net decreases. Based on these arguments, we hypothesise that:

\section{Corporate internet reporting}

185 
MAJ

25,2
H2. Egyptian firms with high profitability are more likely to disclose more information on their web sites than Egyptian firms with low profitability.

\section{Leverage}

Empirical evidence regarding the association between leverage and internet reporting is inconclusive. A positive association was found in Ettredge et al. (2002) and Ismail (2002), while a negative association was found in Brennan and Hourigan (1998), Debreceny et al. (2002), Oyeler et al. (2003), Xiao et al. (2004) and Debreceny and Rahman (2004).

Agency theory has been used to explain the relationship between leverage and corporate disclosure. Increased disclosure can reduce debt holders' inclinations to price-protect against transfers from themselves to shareholders (Xiao et al., 2004). Debreceny et al. (2002) observed that increases in the debt-equity ratio create agency costs. Management could voluntarily disclose on the internet to allow creditors to monitor constantly the affairs of the company and help them assess the ability of the company to pay its obligations on time. Ismail (2002) added that although there are extra costs associated with dissemination of corporate information on the internet, this dissemination might provide more up-to-date reliable information to creditors and would in return reduce agency costs.

In contrast, Oyeler et al. (2003) found that leverage does not explain the decision to use internet for corporate financial reporting. They explained that this may be due to differences between internet reporting and the traditional print-based financial reporting environment and culture, manifested in the differences of costs, benefits and demand and supply structures of the two environments (Oyeler et al., 2003). Based on these arguments, we hypothesise that:

H3. Egyptian firms with a high-leverage ratio are more likely to disclose more information on their web sites than Egyptian firms with low-leverage ratio.

\section{Liquidity}

Abd El Salam (1999) argued that companies, according to signalling theory, will disclose more information if their liquidity ratio is high, to distinguish themselves from other companies with less favourable liquidity. Agency theory suggests that companies with a low-liquidity ratio may provide more information to satisfy the information requirements of shareholders and creditors.

Several studies have examined the relationship between liquidity and the extent of disclosure. However, again the results are mixed. For instance, Oyeler et al. (2003) found that liquidity is considered one of the primary determinants of internet financial reporting among New Zealand companies, and found a positive relationship between company liquidity and voluntary use of internet reporting. However, Wallace et al. (1994) found that companies with lower liquidity provide more information in their annual reports. Other disclosure studies have found no association between disclosure and liquidity (Ahmed and Courtis, 1999). Based on these discussions, we hypothesise that:

H4. More liquid Egyptian firms are more likely to disclose more information on their web sites than less-liquid Egyptian firms. 
Industry type

Industry type has been used in prior studies as a determinant of internet reporting. For example, Lymer (1997), Oyeler et al. (2003), Debreceny et al. (2002), Brennan and Hourigan (1998), Ismail (2002) and Hussainey and Al-Nodel (2008) found a significant association between industry type and the extent of internet reporting. In contrast, Craven and Marston (1999) found no association between the two variables. This may be due to the fact that different industry classifications were used in prior research (i.e. a smaller number of categories may give different results to a larger number of categories).

Signalling theory explains that companies within the same industry tend to adopt the same level of disclosure. If a company within an industry fails to follow the same disclosure practices, including internet disclosures, as others in the same industry, then it may be interpreted as a signal that the company is hiding bad news (Craven and Marston, 1999). We therefore hypothesise that:

H5. The level of internet reporting is more likely to differ among firms in different industry sectors.

\section{Auditor size}

Hail (2002) suggested that audit quality is important factor in improving firms' overall reporting practices. In addition, Xiao et al. (2004, p. 201) argued that international audit firms are more likely to facilitate the diffusion of innovative practices, such as the internet reporting. They explained that:

PriceWaterhouseCoopers has developed EDGARSCAN which can be used to retrieve filings stored in EDGAR and allow automatic comparison of financial statements prepared by different companies [... . The big 5 audit firms also are partners of XBRL (extensible business reporting language) initiated by AICPA and are likely to be better equipped than smaller auditors [...] to advise their clients on IFD (Internet financial reporting).

In prior research, a positive association between audit type and disclosure has been found (Ahmed and Nicholls, 1994; Raffournier, 1995; Xiao et al., 2004). Other researchers found no significant association (Hossain et al., 1995; Abd El Salam, 1999; Wallace et al., 1994). Based on these arguments, we hypothesise that:

H6. Egyptian firms engaging one of the Big 4 international auditing firms are more likely to disclose more information on their web sites than Egyptian firms engaging with other auditing firms.

\section{Foreign listing}

Firms seek foreign listing to obtain funds from the international capital markets at the lowest cost and for other benefits such as wider marketing of products, boosting corporate image and gaining political acceptance by projecting the firm as being "local" in the foreign markets. Firms with a foreign listing face additional disclosure requirements and will provide more information than purely domestically listed companies to comply with the regulation of foreign stock markets if their requirements are greater than, or different to, those of their domestic exchanges (Cooke, 1992). In addition, foreign-listed companies have to disclose more information to reduce information asymmetries between domestic and foreign investors. Internet reporting is used to reduce information asymmetry by its immediate and wide reach (Debreceny et al., 2002).

\section{Corporate internet reporting}

187 
MAJ

25,2

188
Xiao et al. (2004) found a positive association between companies with foreign listing and internet reporting. Debreceny et al. (2002) found that US listing is positively associated with internet reporting, while foreign listing is negatively associated. The high standards of disclosure and regulations in the USA, for example, Securities and Exchange Commission's rule fair disclosure may have induced firms listed in the USA to adopt internet reporting compared to other firms that are not listed in the USA (Debreceny et al., 2002). On the other hand, Oyeler et al. (2003) found no association between internet reporting and foreign listing. We hypothesise that:

H7. Egyptian firms listed in foreign stock exchanges are more likely to disclose more information on their web sites than Egyptian firms listed only in Egyptian stock markets.

\section{Research methodology}

Construction of the disclosure index

The disclosure index used in this study was based on that employed by Xiao et al. (2004) and consisting of 82 items. Xiao et al. index was in turn based on the frameworks of web-based disclosure suggested by Debreceny et al. (2001), Deller et al. (1999), Pirchegger and Wagenhofer (1999) and Marston and Polei (2004). The index consists of 58 items of disclosure content and 24 items of presentation format and accessibility factors. Xiao et al.'s (2004) disclosure index was chosen due to its comprehensiveness (based on four corporate internet disclosure studies which are themselves based on other studies), inclusion of both content and presentation format, and its use by other researchers so aiding comparison of results with previous internet disclosure studies.

Xiao et al. (2004) index composition was adapted to fit the Egyptian environment by adding items found on web sites of the Egyptian companies and extracting items unique to the Chinese environment. For example, the availability of Arabic web sites was added to the index and items, such as resolutions of the board of directors and shareholder meetings, were excluded as they are not relevant in an Egyptian context. In addition, we added the presence/absence of auditor, chairman names and signatures, summary annual reports, appropriation statement (statement of proposed dividend), comparative figures; earning per share and other ratios; corporate governance report; background or history of the organisation, PowerPoint presentation, contact us, link to stock exchange web sites and to securities companies web sites, financial information found in more than one place, credit ratings, conference calls and review of interim financial information.

Web sites text only alternative and chat-room were removed as they are not available on Egyptian companies' web sites. This resulted in a disclosure index, which encompassed 90 items; 59 items of disclosure content and 31 of presentation items (see the Appendix).

We used the unweighted dichotomous disclosure index, which does not focus on a single user group (Bonson-Ponte and Escobar-Rodriguez, 2002). This decision was made for two reasons. First, previous studies employing both weighted and unweighted indices found substantially similar results (Xiao et al., 2004). Second, assigning different weights for different items in the disclosure index may be misleading as the relative importance of each item varies from company to company, industry to industry and time to time (Abd El Salam, 1999). Therefore, if a company discloses (or failed to disclose) 
an item of information, which is included in the index on its web site, it receives a score of $1(0)$.

The disclosure index for each company was calculated by dividing the actual scores awarded by the maximum possible scores appropriate for the company. Therefore, the disclosure index $\left(I_{j}\right)$ for each firm was calculated as follows:

$$
I_{j} \frac{\sum_{i=1}^{n_{j}} X_{i j}}{n_{j_{j}}}
$$

where $n_{j}$ is number of relative items applicable to company $j$; and $X_{i j}=1$ if the item is disclosed; 0, otherwise.

In calculating the index score for a specific company, Marston and Shrives (1991) argued that certain items of disclosure may not be applicable to a specific company. This issue was addressed in the above equation by the actual disclosure score for a company divided by the maximum score possible for that company.

\section{Sample size and data collection}

We selected the Egyptian companies with web sites from amongst the top 100 most active-traded companies listed in the Egyptian Stock Exchange. We deleted two insurance companies from the study, although they had web sites and their web sites included financial information, because they were specialized in nature and were subject to different regulations, tax and accounting rules. For example, the financial statements of Egyptian insurance companies are prepared in accordance with the Egyptian accounting standards related to insurance and reinsurance and law number 10 of 1981 supervision and control of insurance in Egypt and its executive regulations. We also excluded firms with web sites "under construction". This gave us a sample of 62 firms. Of these, only 35 (56 per cent) companies voluntary disclosed financial information on their web sites.

We collected data from company web sites between October 2005 and January 2006. We collected measures of firm's size, profitability, liquidity and leverage. The name of the external auditor and the existence (the absence) of foreign listing are also collected. The web sites were revisited in February 2006 as a validity check and no changes in the companies' web sites were found. In the case of companies whose web sites were under construction, it was confirmed that they were still under construction up to the end of February 2006. Table I shows our independent variables and the expected signs of their hypothesised association with the level of internet reporting.

\section{Empirical results}

Multiple regression analysis is carried out on the 62 Egyptian companies, which had web sites. Data are also transformed before performing the multiple regression to avoid the problems of normality, homogeneity of variance and outliers. Following prior disclosure studies such as Lang and Lundholm (1993, 1996), Cooke (1998) and Al-Htaybat (2005), rank regression is used in this study. This method transforms data into ranks and then applies the regression technique. Rank scores used in this research were calculated using the Lang and Lundholm (1993) formulae:
Corporate internet reporting

189 
MAJ
25,2

Table I.

Independent variables measures

\begin{tabular}{|c|c|c|}
\hline Hypothesis & Expected sign & Measures \\
\hline Firm size & + & Total assets \\
\hline Profitability & + & ROE (net profit/equity) \\
\hline Leverage & + & Total debt/total assets \\
\hline Liquidity & + & $\begin{array}{l}\text { Current ratio (current asset/current liability) } \\
=1 \text { for companies that are audited by one of the Big }\end{array}$ \\
\hline Auditor size & + & $\begin{array}{l}4 \text { audit firms; } 0 \text { otherwise } \\
=1 \text { for companies that are listing their stock in }\end{array}$ \\
\hline Foreign listing & + & foreign countries; 0 otherwise \\
\hline Industrial sector & \pm & $\begin{array}{l}1 \text { - Construction } \\
2 \text { - Chemicals } \\
3 \text { - Communications } \\
4 \text { - Financial services } \\
5 \text { - Food and beverage } \\
6 \text { - Entertainment } \\
7 \text { - Textile and clothing } \\
8 \text { - Engineering and mining } \\
9 \text { - Utilities }\end{array}$ \\
\hline
\end{tabular}

$$
\text { Percentile rank }=\frac{\text { Rank }-1}{\text { Number of companies }-1} .
$$

Three dependent variables were used for internet reporting, namely, content, format and total score (which includes both content and format). To test our hypotheses, we use the following equation[3]:

DI $($ Total score, content, format $)=\beta_{0}+\beta_{1}$ Size $+\beta_{2}$ Profitability $+\beta_{3}$ Leverage

$$
+\beta_{4} \text { Liquidity }+\beta_{5} \text { Auditor }+\beta_{6} \text { Foreign listing }
$$$$
+\beta_{7} \text { Construction }+\beta_{8} \text { Chemical }
$$

$+\beta_{9}$ Communication $+\beta_{10}$ Financial service

$+\beta_{11}$ Food and beverage $+\beta_{12}$ Entertainment

$+\beta_{13}$ Textile and clothing $+\varepsilon_{I}$

where:

$$
\begin{aligned}
& \text { DI - disclosure index. } \\
& \beta_{0} \text { - intercept. } \\
& \boldsymbol{\varepsilon}_{I} \text { - residual. }
\end{aligned}
$$

Full rank and normal score transformation regression models were run for each of the dependent variables: total score, total content and total format. Histograms and normal distribution plots were employed once more to evaluate the normality of the residual distribution. For all models, the rank residual was normally distributed. The Durbin-Watson statistic was calculated for all models and its value was close to 2 . The Durbin-Watson statistic is used to test whether the assumption of independent error is tenable; the closer the value to 2 , the better, as it means that the assumption has 
been met (Field, 2005). The variance inflation factor (VIF) was inspected for models to ensure that the problem of multicollinearity did not exist. The VIF should be lower than 10 and tolerance should not be below 0.2 (Field, 2005), which was the case with all the models after using rank and normal regression.

Tables II-IV report the results of the rank regression when using total score, total content and total format as dependent variables, respectively. Furthermore, Tables V-VII show the results of the normal score regression when using total score, total content and total format as dependent variables, respectively.

Table II shows that the ranked score regression of the total score model explained around 65.3 per cent of the variance, measured by adjusted $R^{2}$ with an $F$-ratio of 9.837 ,

\section{Corporate internet reporting}

191

\begin{tabular}{lccccccc}
\hline Coefficients & $B$ & SE & $\beta$ & $t$ & Sig. & Tolerance & VIF \\
\hline Constant & 0.031 & 0.119 & & 0.256 & 0.799 & & \\
Total assets & 0.091 & 0.113 & 0.091 & 0.801 & 0.427 & 0.442 & 2.264 \\
ROE & 0.204 & 0.092 & 0.204 & 2.207 & $0.032^{*}$ & 0.665 & 1.503 \\
Tdbt/TA & 0.069 & 0.141 & 0.069 & 0.487 & 0.629 & 0.284 & 3.517 \\
CA/CL & 0.064 & 0.104 & 0.064 & 0.612 & $0.544 *$ & 0.520 & 1.923 \\
Foreign listing & 0.191 & 0.088 & 0.229 & 2.176 & $0.035^{*}$ & 0.512 & 1.951 \\
Audit firm type & 0.054 & 0.060 & 0.092 & 0.908 & 0.369 & 0.551 & 1.813 \\
Construction & 0.107 & 0.101 & 0.134 & 1.060 & 0.294 & 0.354 & 2.821 \\
Chemicals & 0.112 & 0.108 & 0.113 & 1.038 & 0.305 & 0.482 & 2.075 \\
Communications & 0.519 & 0.138 & 0.482 & 3.762 & $0.000^{* *}$ & 0.346 & 2.889 \\
Financial services & 0.358 & 0.106 & 0.579 & 3.372 & $0.001^{* *}$ & 0.193 & 5.184 \\
Food and beverage & -0.063 & 0.113 & -0.059 & -0.556 & 0.581 & 0.512 & 1.955 \\
Entertainment & 0.074 & 0.104 & 0.075 & 0.711 & 0.480 & 0.517 & 1.934 \\
Textile and clothing & 0.144 & 0.127 & 0.105 & 1.135 & 0.262 & 0.661 & 1.512
\end{tabular}

Notes: Significant at: ${ }^{*} 0.05$ and ${ }^{* *} 0.01$ levels, respectively; $R=0.853 ; R^{2}=0.727$; adjusted model of total score for 62 $R^{2}=0.653 ; \mathrm{SE}$ of the estimate $=0.17395 ; R^{2}$-change $=0.727 ; F$-change $=9.837 ;$ sig. $F=0.000$ companies

\begin{tabular}{lrcrrrrr}
\hline Coefficients & $B$ & SE & $\beta$ & \multicolumn{1}{c}{$t$} & Sig. & Tolerance & VIF \\
\hline Constant & -0.008 & 0.112 & & -0.075 & 0.941 & & \\
Total assets & 0.170 & 0.106 & 0.171 & 1.608 & 0.114 & 0.442 & 2.264 \\
ROE & 0.149 & 0.086 & 0.150 & 1.730 & 0.090 & 0.665 & 1.503 \\
Tdbt/TA & 0.049 & 0.132 & 0.049 & 0.369 & 0.714 & 0.284 & 3.517 \\
CA/CL & 0.063 & 0.098 & 0.063 & 0.642 & 0.524 & 0.520 & 1.923 \\
Foreign listing & 0.138 & 0.082 & 0.167 & 1.690 & 0.098 & 0.512 & 1.951 \\
Audit firm type & 0.097 & 0.056 & 0.166 & 1.742 & 0.088 & 0.551 & 1.813 \\
Construction & 0.174 & 0.094 & 0.219 & 1.845 & 0.071 & 0.354 & 2.821 \\
Chemicals & 0.193 & 0.101 & 0.196 & 1.920 & 0.061 & 0.482 & 2.075 \\
Communications & 0.532 & 0.129 & 0.496 & 4.123 & $0.000 *$ & 0.346 & 2.889 \\
Financial services & 0.358 & 0.099 & 0.580 & 3.596 & $0.001 *$ & 0.193 & 5.184 \\
Food and beverage & -0.005 & 0.106 & -0.005 & -0.046 & 0.964 & 0.512 & 1.955 \\
Entertainment & 0.026 & 0.097 & 0.026 & 0.265 & 0.792 & 0.517 & 1.934 \\
Textile and clothing & 0.199 & 0.118 & 0.147 & 1.684 & 0.099 & 0.661 & 1.512
\end{tabular}

Notes: Significant at: ${ }^{*} 0.01$ level; $R=0.872 ; R^{2}=0.760$; adjusted $R^{2}=0.694 ;$ SE of the model of total content for estimate $=0.16273 ; R^{2}$-change $=0.760 ; F$-change $=11.662 ;$ sig. $F=0.000$ 
MAJ
25,2

Table IV.

Full rank regression model of total format for 62 companies

\begin{tabular}{lccccccc}
\hline Coefficients & $B$ & SE & $\beta$ & $t$ & Sig. & Tolerance & VIF \\
\hline Constant & 0.061 & 0.136 & & 0.449 & 0.656 & & \\
Total assets & 0.025 & 0.130 & 0.025 & 0.190 & 0.850 & 0.442 & 2.264 \\
ROE & 0.298 & 0.106 & 0.299 & 2.819 & $0.007^{* *}$ & 0.665 & 1.503 \\
Tdbt/TA & 0.121 & 0.161 & 0.122 & 0.750 & 0.457 & 0.284 & 3.517 \\
CA/CL & 0.021 & 0.119 & 0.021 & 0.173 & 0.863 & 0.520 & 1.923 \\
Foreign listing & 0.278 & 0.100 & 0.335 & 2.770 & $0.008^{* *}$ & 0.512 & 1.951 \\
Audit firm type & 0.029 & 0.068 & 0.050 & 0.430 & 0.669 & 0.551 & 1.813 \\
Construction & 0.032 & 0.115 & 0.041 & 0.281 & 0.780 & 0.354 & 2.821 \\
Chemicals & 0.048 & 0.123 & 0.049 & 0.393 & 0.696 & 0.482 & 2.075 \\
Communications & 0.372 & 0.158 & 0.347 & 2.360 & $0.022^{*}$ & 0.346 & 2.889 \\
Financial services & 0.290 & 0.122 & 0.469 & 2.382 & $0.021^{*}$ & 0.193 & 5.184 \\
Food and beverage & -0.073 & 0.130 & -0.068 & -0.564 & 0.575 & 0.512 & 1.955 \\
Entertainment & 0.151 & 0.119 & 0.153 & 1.269 & 0.211 & 0.517 & 1.934 \\
Textile and clothing & 0.098 & 0.145 & 0.072 & 0.680 & 0.500 & 0.661 & 1.512
\end{tabular}

Notes: Significant at: ${ }^{*} 0.05$ and ${ }^{* *} 0.01$ levels, respectively; $R=0.801 ; R^{2}=0.641 ;$ adjusted $R^{2}=0.544 ; \mathrm{SE}$ of the estimate $=0.19891 ; R^{2}$-change $=0.641 ; F$-change $=6.596 ;$ sig. $F=0.000$

Table V.

Normal score regression model of total score for 62 companies

\begin{tabular}{lrrrrrrr}
\hline Coefficients & $B$ & $\mathrm{SE}$ & $\beta$ & \multicolumn{1}{c}{$t$} & Sig. & Tolerance & VIF \\
\hline Constant & -0.713 & 0.261 & & -2.733 & 0.009 & & \\
Total assets & 0.072 & 0.120 & 0.073 & 0.603 & 0.550 & 0.436 & 2.294 \\
ROE & 0.235 & 0.096 & 0.237 & 2.449 & $0.018^{*}$ & 0.677 & 1.478 \\
Tdbt/TA & 0.051 & 0.133 & 0.052 & 0.384 & 0.702 & 0.350 & 2.855 \\
CA/CL & 0.052 & 0.109 & 0.053 & 0.477 & 0.635 & 0.522 & 1.914 \\
Foreign listing & 0.618 & 0.298 & 0.233 & 2.074 & $0.043^{*}$ & 0.503 & 1.990 \\
Audit firm type & 0.101 & 0.200 & 0.054 & 0.506 & 0.615 & 0.553 & 1.808 \\
Construction & 0.341 & 0.338 & 0.134 & 1.008 & 0.318 & 0.357 & 2.798 \\
Chemicals & 0.214 & 0.361 & 0.068 & 0.592 & 0.557 & 0.485 & 2.060 \\
Communications & 1.660 & 0.474 & 0.484 & 3.499 & $0.001^{* *}$ & 0.332 & 3.014 \\
Financial services & 1.030 & 0.339 & 0.521 & 3.037 & $0.004^{* *}$ & 0.215 & 4.650 \\
Food and beverage & -0.353 & 0.379 & -0.103 & -0.931 & 0.356 & 0.519 & 1.926 \\
Entertainment & 0.200 & 0.350 & 0.063 & 0.572 & 0.570 & 0.516 & 1.938 \\
Textile and clothing & 0.476 & 0.424 & 0.109 & 1.124 & 0.267 & 0.670 & 1.493
\end{tabular}

Notes: Significant at: ${ }^{*} 0.05$ and ${ }^{* *} 0.01$ levels, respectively; $R=0.834 ; R^{2}=0.696$; adjusted $R^{2}=0.614$; SE of the estimate $=0.5858892 ; R^{2}$-change $=0.696 ; F$-change $=8.453$; sig. $F=0.000$

which is significant with a probability less than 0.001 . Field (2005) clarified that the $F$-ratio is used to test the overall fit of the model; a good model should have an $F$-ratio greater than 1 . Table III shows that the ranked score regression of the content model explained around 69.4 per cent of the variance, measured by adjusted $R^{2}$ with an $F$-ratio of 11.662, which is significant with a probability less than 0.001 . Table IV shows that the ranked score regression of the total format model explained around 54.4 per cent of the variance, measured by adjusted $R^{2}$ with an $F$-ratio of 6.596 , which is significant with a probability less than 0.001 . The $t$-tests showed that return on equity (ROE), foreign listing and industrial sector (communications and financial services sectors) had a significant association with the level of internet reporting (total score and format). However, only the 


\begin{tabular}{lrrrrrrr}
\hline Coefficients & $B$ & SE & $\beta$ & $t$ & Sig. & Tolerance & VIF \\
\hline Constant & -0.878 & 0.226 & & -3.892 & $0.000 *$ & & \\
Total assets & 0.222 & 0.103 & 0.228 & 2.150 & $0.037^{*}$ & 0.436 & 2.294 \\
ROE & 0.151 & 0.083 & 0.155 & 1.820 & 0.075 & 0.677 & 1.478 \\
Tdbt/TA & 0.002 & 0.115 & 0.002 & 0.017 & 0.986 & 0.350 & 2.855 \\
CA/CL & 0.073 & 0.094 & 0.075 & 0.773 & 0.443 & 0.522 & 1.914 \\
Foreign listing & 0.322 & 0.258 & 0.124 & 1.250 & 0.217 & 0.503 & 1.990 \\
Audit firm type & 0.342 & 0.173 & 0.187 & 1.978 & 0.054 & 0.553 & 1.808 \\
Construction & 0.600 & 0.293 & 0.241 & 2.051 & $0.046^{*}$ & 0.357 & 2.798 \\
Chemicals & 0.571 & 0.312 & 0.184 & 1.829 & 0.074 & 0.485 & 2.060 \\
Communications & 1.758 & 0.410 & 0.522 & 4.284 & $0.000^{* *}$ & 0.332 & 3.014 \\
Financial services & 1.000 & 0.293 & 0.516 & 3.410 & $0.001^{* *}$ & 0.215 & 4.650 \\
Food and beverage & 0.059 & 0.328 & 0.017 & 0.179 & 0.859 & 0.519 & 1.926 \\
Entertainment & -0.051 & 0.303 & -0.017 & -0.169 & 0.866 & 0.516 & 1.938 \\
Textile and clothing & 0.684 & 0.366 & 0.160 & 1.867 & 0.068 & 0.670 & 1.493
\end{tabular}

Notes: Significant at: ${ }^{*} 0.05$ and ${ }^{* *} 0.01$ levels, respectively; $R=0.874 ; R^{2}=0.764$; adjusted $R^{2}=0.700 ; \mathrm{SE}$ of the estimate $=0.5066906 ; R^{2}$-change $=0.764 ; F$-change $=11.941 ;$ sig. $F=0.000$

Corporate internet reporting

193

Table VI. Normal score regression model of total content for 62 companies

\begin{tabular}{lrrrrrrr}
\hline Coefficients & $B$ & SE & \multicolumn{1}{c}{$\beta$} & \multicolumn{1}{c}{$t$} & Sig. & Tolerance & VIF \\
\hline Constant & -0.571 & 0.297 & & -1.926 & 0.060 & & \\
Total assets & -0.013 & 0.136 & -0.013 & -0.096 & 0.924 & 0.436 & 2.294 \\
ROE & 0.311 & 0.109 & 0.314 & 2.847 & $0.006 * *$ & 0.677 & 1.478 \\
Tdbt/TA & 0.110 & 0.152 & 0.111 & 0.722 & 0.474 & 0.350 & 2.855 \\
CA/CL & 0.026 & 0.124 & 0.027 & 0.212 & 0.833 & 0.522 & 1.914 \\
Foreign listing & 0.899 & 0.339 & 0.340 & 2.651 & $0.011^{*}$ & 0.503 & 1.990 \\
Audit firm type & 0.105 & 0.228 & 0.056 & 0.462 & 0.646 & 0.553 & 1.808 \\
Construction & 0.028 & 0.385 & 0.011 & 0.074 & 0.942 & 0.357 & 2.798 \\
Chemicals & 0.033 & 0.411 & 0.011 & 0.081 & 0.935 & 0.485 & 2.060 \\
Communications & 1.054 & 0.540 & 0.308 & 1.952 & 0.057 & 0.332 & 3.014 \\
Financial services & 0.803 & 0.386 & 0.408 & 2.081 & $0.043 *$ & 0.215 & 4.650 \\
Food and beverage & -0.393 & 0.431 & -0.115 & -0.911 & 0.367 & 0.519 & 1.926 \\
Entertainment & 0.424 & 0.399 & 0.134 & 1.063 & 0.293 & 0.516 & 1.938 \\
Textile and clothing & 0.297 & 0.482 & 0.068 & 0.616 & 0.541 & 0.670 & 1.493
\end{tabular}

Notes: Significant at: ${ }^{*} 0.05$ and ${ }^{* *} 0.01$ levels, respectively; $R=0.777 ; R^{2}=0.604$; adjusted $R^{2}=0.497 ; \mathrm{SE}$ of the estimate $=0.6665766 ; R^{2}$-change $=0.604 ; F$-change $=5.635 ;$ sig. $F=0.000$

Normal score regression model of total format for 62 companies

industrial sector (communications and financial services sectors) was significant for content.

Tables V-VII show the results of the normal score ordinary least square (OLS) regression model for the 62 companies, which had web sites. The first model, total score, explained 61.4 per cent of the variance measured by adjusted $R^{2}$ with an $F$-ratio of 8.453 , which is significant with a probability less than 0.001 . The second model, total content, explained 76.4 per cent of the variance measured by adjusted $R^{2}$ with an $F$-ratio of 11.941 , which is significant with a probability less than 0.001 . The third model, format explained 49.7 per cent of the variance measured by adjusted $R^{2}$ with an 
MAJ

25,2

194

$F$-ratio of 5.635, which is significant with a probability less than 0.001 . For the first and last models, $t$-tests showed profitability (ROE), foreign listing and industrial sector were significantly associated with the level of internet reporting (total score and format) at the 5 per cent level. However, the type of business, mainly construction, communications and financial services, significantly affects the content of disclosure of financial information of the internet, as well as total assets.

Table VIII provides a summary of ranked and normal score regression analyses. It shows that there is a positive relationship between the profitability (ROE) of the Egyptian companies, which have web sites and the formats they use to disclose the financial information on their web sites. This indicates that profitable companies use more formatting techniques to simplify the acquisition of the information from their web sites. These results are consistent with prior research on internet reporting in developing countries (Ismail, 2002).

In addition, we find that foreign listing affects the formats companies use. Companies that are listed on more than one stock exchange make it easier for stakeholders to acquire the information from their web sites. They display the information in more than one place with different formatting to make it easier to download or save. These findings are in line with Xiao et al. (2004).

Finally, we find that the industry type (communication and financial services) affects the amount and formatting of financial information displayed on companies' web sites. The results are consistent with prior research on online disclosure in developing countries (Ismail, 2002; Oyelere et al., 2003; Xiao et al., 2004; Hussainey and Al-Nodel, 2008).

\section{Discussion and conclusions}

The objective of this study is to explore the association between key firm characteristics and the level of internet reporting by Egyptian companies. It uses a disclosure index to explore the content and the presentation format for individual company's web sites. Of the 98 companies surveyed, only 68 had web sites. The results for the sample of 62 companies listed in the Egyptian Stock Exchange show that over

\begin{tabular}{|c|c|c|c|c|c|c|}
\hline \multirow[b]{3}{*}{ Table number } & \multicolumn{2}{|c|}{ Total score } & \multicolumn{2}{|c|}{ Total content } & \multicolumn{2}{|c|}{ Format } \\
\hline & $\mathrm{R}$ & $\mathrm{N}$ & $\mathrm{R}$ & $\mathrm{N}$ & $\mathrm{R}$ & $\mathrm{N}$ \\
\hline & 7 & 10 & 8 & 11 & 9 & 12 \\
\hline Total assets & & & & レ & & \\
\hline ROE & $\nu$ & $\boldsymbol{\nu}$ & & & $\boldsymbol{\nu}$ & レ \\
\hline Tdbt/TA & & & & & & \\
\hline $\mathrm{CA} / \mathrm{CL}$ & & & & & & \\
\hline Foreign listing & $\nu$ & $\nu$ & & & $\nu$ & r \\
\hline Audit firm type & & & & & & \\
\hline Construction & & & & $r$ & & \\
\hline Chemical & & & & & & \\
\hline Communication & $\boldsymbol{\nu}$ & $\boldsymbol{\nu}$ & $\nu$ & $\nu$ & $\nu$ & \\
\hline Financial services & $\nu$ & $\nu$ & $\nu$ & $\nu$ & $\nu$ & v \\
\hline Food and beverage & & & & & & \\
\hline Entertainment & & & & & & \\
\hline Textile and clothing & & & & & & \\
\hline
\end{tabular}

Table VIII. Summary of the ranked and normal OLS regression results

\section{Textile and clothing}


50 per cent of Egyptian companies voluntarily report financial information on their web sites. The results also show that profitability, foreign listing and industrial sector (communications and financial services) are the most important factors that affect the amount and the presentation formats of internet reporting in Egypt.

This paper is the first to examine the potential factors affecting corporate internet reporting in Egypt. The disclosure index used was designed to be suitable for companies working in the Egyptian environment. Therefore, it could be used by other researchers to investigate the internet reporting in other Arab countries that are experiencing business and economic environments.

This study presents a snapshot of internet financial reporting of Egyptian companies from October 2005 to January 2006. As internet reporting is a new phenomenon in Egypt, this study could not examine the longitudinal data of internet reporting, and so is limited to a cross-sectional study. However, this study provides a base for future longitudinal studies of internet reporting in Egypt. Owing to the newness of company web sites in Egypt, the number of companies in this study was relatively small. Therefore, it is difficult to generalise the results.

The explanatory power in the multiple regression analysis ranged between 50 and 76 per cent; although this percentage is considerable, it might indicate that other variables that were not included in the model affect the level of disclosure. Therefore, future studies might usefully employ interviews to uncover other factors, such as religion, culture, organisational change and demographic characteristics, which could affect internet financial reporting and disclosure in Egypt.

This study was not designed to explore the economic consequences of internet reporting, e.g. the extent to which internet financial reporting provides value-relevant information for investors. Future research might test empirically how internet disclosure impacts upon companies' stock prices.

In addition, research has shown that firms tend to disclose more information in order to reduce information asymmetry between themselves and investors. By attracting more investors to the firm, the cost of capital is expected to be reduced for the company. Therefore, the relationship between the level of internet financial reporting and disclosure and cost of capital could be examined in future research.

Research is also required to explore how differences in presentation format of information affect user decisions. This could be undertaken by conducting an experiment to study the effects of different hypertext links and interfaces on users' decisions and predictions, the amount of information accessed, and the time taken to make decisions.

This study used unweighted disclosure index, which means that all information items are assumed to have the same degree of importance for investors. However, future studies could use a weighted disclosure index with questionnaires used to solicit the relative importance of different types of, and ways of disclosing, financial and non-financial information for various user groups.

Recently, corporate governance has become an important issue in both developed and developing countries. In October 2005, Egypt adopted a draft Corporate Governance Code based on the principles of corporate governance that were developed by the Organisation for Economic Cooperation \& Development (OECD), one of the pioneers in setting corporate governance standards (Mohieldin, 2006). Corporate governance is concerned with the relationship between management, board of directors and other shareholders. Corporate governance should be considered in
Corporate internet reporting

195 
MAJ

25,2

196

internet disclosures as it is the board of directors that manage the disclosure of information. Therefore, future research might consider the association between both corporate governance characteristics and firm characteristics and the level of corporate internet reporting.

This study investigated the extent of internet reporting and characteristics of companies adopting internet financial reporting and as such it focused on supply rather than demand. Therefore, a better understanding of the different needs of users and the potential for effective reporting activity could be achieved by measuring demand side factors such as the frequency of visits to corporate web sites to download or view financial information.

\section{Notes}

1. For more information about the Egyptian Stock Exchange, please visit: www.egyptse.com/ index.asp

2. Three recent studies have examined the determinants of corporate disclosure in Egypt. These include Hassan et al. (2006); AbdelFattah et al. (2008) and Iskander et al. (2008). However, these studies limit their analyses to the information disclosed in the annual report. However, our study uses a comprehensive source of information - the company web sites. This includes, in addition to the annual report, other useful reports such as the interim report. It also contains more timely and updated information, which is needed by stakeholders in the decision-making process.

3. Industry type contains nine sectors in this study. Since only one company belonged to the utilities sector, this sector was not included. This left eight sectors and eight dummy variables, of which one needed to be excluded, since the number of dummy variables should be one less than the number of levels of the nonmetric variables (Hair et al., 1998). One dummy variable is not used as it would overlap completely with the variation explained by the other dummy variables and this would result in multicollinearity, which should be avoided in multiple regression (Howitt and Cramer, 1997). The exclusion of this one dummy variable will not result in omission of information as it has already been accounted for by the other dummy variables (Howitt and Cramer, 1997). Therefore, it was decided in this study to exclude engineering and mining from multiple regression. The seven dummy variables of industries are construction, chemicals, communications, financial service, food and beverage, entertainment and textile and clothing. Each variable was given the value of 1 if the company belonged to this particular industry and 0 otherwise.

\section{References}

AbdelFattah, T., Dixon, R. and Woodhead, A. (2008), "Corporate governance and voluntary disclosure in emerging capital markets: evidence from Egypt", working paper, Durham University, Durham.

Abd El Salam, O.H. (1999), "The introduction and application of international accounting standards to accounting disclosure regulations of a capital market in developing country: the case of Egypt", $\mathrm{PhD}$ thesis, Heriot-Watt University, Edinburgh.

Ahmed, K. and Courtis, J.K. (1999), "Associations between corporate characteristics and disclosure levels in annual reports: a meta-analysis", The British Accounting Review, Vol. 31 No. 1, pp. 35-61.

Ahmed, K. and Nicholls, D. (1994), "The impact of non-financial company characteristics on mandatory disclosure compliance in developing countries: the case of Bangladesh", The International Journal of Accounting, Vol. 29, pp. 62-77. 
AlDeesty, M. (2004), "Accounting and auditing on the internet between practice and expectations: comparative empirical study for large Egyptian and American companies", Egyptian Journal of Commerce Studies, Vol. 4, pp. 1-36.

Al-Htaybat, K. (2005), "Financial disclosure practices: theoretical foundation, and an empirical investigation on Jordanian printed and internet formats", $\mathrm{PhD}$ thesis, University of Southampton, Southampton.

Al-Htaybat, K. and Napier, C. (2006), "Online corporate financial reporting in developing countries: the case of Jordan", paper presented at the BAA Annual Conference, Portsmouth University, Portsmouth.

Allam, A. and Lymer, A. (2003), "Developments in internet financial reporting: review and analysis across five developed countries", The International Journal of Digital Accounting Research, Vol. 3 No. 6, pp. 165-206.

Ashbaugh, H., Johnstone, K.M. and Warfield, T.D. (1999), “Corporate reporting on the internet”, Accounting Horizons, Vol. 13 No. 3, pp. 241-57.

Bonson-Ponte, E. and Escobar-Rodriguez, T. (2002), "A survey on voluntary disclosure on the internet: empirical evidence from 300 European Union companies", The International Journal of Digital Accounting Research, Vol. 2 No. 3, pp. 27-52.

Booker, J.A. and Galbreath, S.C. (1997), "Financial information and the WWW current state of reporting practices", National Public Accountant, Vol. 42 No. 8, p. 32.

Brennan, N. and Hourigan, D. (1998), "Corporate reporting on the internet by Irish companies", Accountancy Ireland, Vol. 30 No. 6, pp. 18-21.

Chan, W.K. and Wickramasinghe, N. (2006), "Using the internet for financial disclosures: the Australian experience”, International Journal of Electronic Finance, Vol. 1 No. 1, pp. 118-50.

Cooke, T.E. (1989), "Disclosure in the corporate annual reports of Swedish companies", Accounting \& Business Research, Vol. 19 No. 34, pp. 113-24.

Cooke, T.E. (1991), "An assessment of voluntary disclosure in the annual reports of Japanese corporation”, International Journal of Accounting, Vol. 26 No. 3, pp. 174-89.

Cooke, T.E. (1992), "The impact of size, stock market listing and industry type on disclosure in the annual reports of Japanese listed corporations", Accounting \& Business Research, Vol. 22 No. 87, pp. 229-37.

Cooke, T.E. (1993), "Disclosure in Japanese corporate annual reports", Journal of Business, Finance and Accounting, Vol. 20 No. 4, pp. 521-35.

Cooke, T.E. (1998), "Regression analysis in accounting disclosure studies", Accounting \& Business Research, Vol. 28 No. 3, pp. 209-24.

Craven, B.M. and Marston, C.L. (1999), "Financial reporting on the internet by leading UK companies", The European Accounting Review, Vol. 8 No. 2, pp. 321-33.

Davey, H. and Homkajohn, K. (2004), "Corporate internet reporting: an Asian example”, Problems and Perspectives in Management, Vol. 2, pp. 211-27.

Debreceny, R. and Rahman, A. (2004), "Market and firm specific determinants of continuous corporate disclosures", paper presented at the International Accounting Conference, Athens University of Economics and Business, Athens.

Debreceny, R., Gray, G.L. and Mock, T.J. (2001), "Financial reporting websites: what users want in terms of form and content", The International Journal of Digital Accounting Research, Vol. 1 No. 1, pp. 1-26.

Debreceny, R., Gray, G.L. and Rahman, A. (2002), "The determinants of internet financial reporting", Journal of Accounting \& Public Policy, Vol. 21 Nos 4/5, pp. 371-95. 
MAJ

25,2

198

Deller, D., Stubenrath, M. and Weber, C. (1999), "A survey on the use of the internet for investor relations in the USA, the UK and Germany", European Accounting Review, Vol. 8 No. 2, pp. 351-64.

Ettredge, M., Richardson, V.J. and Scolz, S. (2002), "Dissemination of information for investors at corporate web site”, Journal of Accounting \& Public Policy, Vol. 21 Nos 4/5, pp. 357-69.

Field, A. (2005), Discovering Statistics Using SPSS: (and Sex, Drugs and Rock " $n$ ” Roll), Sage, London.

Fisher, R., Oyelere, P. and Laswad, F. (2004), "Corporate reporting on the internet: audit issues and content analysis of practices”, Managerial Auditing Journal, Vol. 19 No. 3, pp. 412-39.

Gowthorpe, C. and Flynn, G. (1997), "Reporting on the web: state of the art", Accountancy: International Edition, Vol. 120 No. 1248, pp. 58-9.

Hail, L. (2002), "The impact of voluntary corporate disclosures on the ex ante cost of capital for Swiss firms", European Accounting Review, Vol. 11 No. 11, pp. 741-73.

Hair, J.F., Anderson, R.E., Tatham, R.L. and Black, W.C. (1998), Multivariate Data Analysis, Prentice-Hall International, Upper Saddle River, NJ.

Hamid, F.Z.A. (2005), "Malaysian companies' use of the internet for investor relations", Corporate Governance, Vol. 5 No. 1, pp. 5-14.

Hassan, O., Giorgioni, G. and Romilly, P. (2006), "The extent of accounting disclosure and its determinants in an emerging capital market: the case of Egypt", International Journal of Accounting, Auditing and Performance Evaluation, Vol. 3 No. 1, pp. 41-67.

Hedlin, P. (1999), "The internet as a vehicle for investor relations: the Swedish case", European Accounting Review, Vol. 8 No. 2, pp. 373-81.

Hossain, M., Perera, M.H.B. and Rahman, A.R. (1995), "Voluntary disclosure in the annual reports of New Zealand companies", Journal of International Financial Management \& Accounting, Vol. 6 No. 1, pp. 69-87.

Howitt, D. and Cramer, D. (1997), A Guide to Computing Statistics with SPSS for Windows, Prentice-Hall/Harvester Wheatsheaf, New York, NY.

Hussainey, K. and Al-Nodel, A. (2008), "Corporate governance online reporting by Saudi listed companies", Research in Accounting in Emerging Economics, Vol. 8, pp. 39-64.

Hussey, R. and Sowinska, M. (1999), “The risks of financial reports on the internet”, Accounting \& Business, March, pp. 18-19.

Iskander, A., Salama, A. and Dixon, R. (2008), "Categories and determinants of voluntary corporate disclosure: some Egyptian evidence”, working paper, Durham University, Durham.

Ismail, T.H. (2002), "An empirical investigation of factors influencing voluntary disclosure of financial information on the internet in the GCC countries", available at: http://ssrn.com/ abstract $=420700$

Kamel, S. and Hussein, M. (2001), "The development of e-commerce: the emerging virtual context within Egypt", Logistics Information Management, Vol. 14 Nos 1/2, pp. 119-26.

Kamel, S. and Hussein, M. (2002), "The emergence of e-commerce in a developing nation", Benchmarking: An International Journal, Vol. 9 No. 2, pp. 146-53.

Lang, M.H. and Lundholm, R.J. (1993), "Cross-sectional determinants of analyst ratings of corporate disclosures", Journal of Accounting Research, Vol. 31 No. 2, pp. 246-71.

Lang, M.H. and Lundholm, R.J. (1996), "Corporate disclosure policy and analyst behaviour", The Accounting Review, Vol. 71 No. 4, pp. 467-92.

Larran, M. and Giner, B. (2002), "The use of the internet for corporate reporting by Spanish companies", The International Journal of Digital Accounting Research, Vol. 2 No. 3, pp. 53-82. 
Lodhia, S.K., Allam, A. and Lymer, A. (2004), "Corporate reporting on the internet in Australia: an exploratory study", Australian Accounting Review, Vol. 14 No. 3, pp. 64-71.

Louwers, T.J., Pasewark, W.R. and Typpo, E.W. (1996), "The internet: changing the way corporations tell their story”, CPA Journal, Vol. 6 No. 11, pp. 24-8.

Lymer, A. (1997), "Corporate reporting via the internet - a survey of current usage in the UK and discussion of issues", paper presented at the 1st Financial Reporting and Business Communication Conference, Cardiff.

McKinnon, J. and Dalimunthe, L. (1993), "Voluntary disclosure of segment information by Australian diversified companies”, Accounting \& Finance, Vol. 33 No. 1, pp. 33-50.

Marston, C. (2003), "Financial reporting on the internet by leading Japanese companies", Corporate Communications, Vol. 8 No. 1, pp. 23-7.

Marston, C. and Leow, C.Y. (1998), "Financial reporting on the internet by leading UK companies", paper presented at the 21st Annual Congress of the European Accounting Association, Antwerp.

Marston, C. and Polei, A. (2004), "Corporate reporting on the internet by German companies", International Journal of Accounting Information Systems, Vol. 5 No. 3, pp. 285-311.

Marston, C. and Shrives, P. (1991), "The use of disclosure indices in accounting research: a review article”, British Accounting Review, Vol. 23, pp. 195-210.

Metwali, T. (2003), "Financial reporting on the internet: a study on the Egyptian business environment”, Egyptian Journal of Commercial Studies, Vol. 1, pp. 273-321.

Mintz, S. (1998), “The internet as a tool for Egypt's economic growth”, An International Development Professionals Inc. Report, International Development Professionals, Burke, VA, October.

Mohamed, F. (2002), "Financial reporting on the internet: a survey of Egyptian, Saudi Arabian, and Kuwaiti companies", Journal of Financial and Commercial Studies, Vol. 3, pp. 203-27.

Mohieldin, M. (2006), "Corporate governance in Egypt: how will the government apply it and how will it affect your bottom line?", available at: www.amcham.org.eg/operation/events/ events06/Mohieldine_breakfast/Mohieldine.asp

Nafie, I. (2001), "A double dividend", Al-Ahram Weekly On-line, No. 523, available at: http:// weekly.ahram.org.eg/2001/523/op1.htm (accessed 5 May 2005).

Oyeler, P., Laswad, F. and Fisher, R. (2003), "Determinants of internet financial reporting by New Zealand companies", Journal of International Management and Accounting, Vol. 14 No. 1, pp. 26-63.

Pirchegger, B. and Wagenhofer, A. (1999), "Financial information on the internet: a survey of the homepages of Australian companies”, European Accounting Review, Vol. 8 No. 2, pp. 383-95.

Raffournier, B. (1995), "The determinants of voluntary financial disclosure by Swiss listed companies", European Accounting Review, Vol. 4 No. 2, pp. 261-80.

Ragab, A.A. and Omran, M.M. (2006), “Accounting information, value relevance, and investors' behaviour in the Egyptian equity market", Review of Accounting and Finance, Vol. 5 No. 3, pp. 279-97.

Ruland, W., Tung, S. and George, N. (1990), "Factors associated with the disclosure of managers' forecasts", Accounting Review, Vol. 65 No. 7, pp. 10-21.

Street, D.L. and Gray, S.J. (2002), "Factors influencing the extent of corporate compliance with International Accounting Standards: summary of a research monograph", Journal of International Accounting, Auditing \& Taxation, Vol. 11, pp. 51-76. 
MAJ

25,2

200
Trabelsi, S. (2007), "An empirical examination of corporate website as a voluntary disclosure medium”, paper presented at the BAA Annual Conference, Royal Holloway, University of London, London.

Trabelsi, S., Labelle, R. and Laurin, C. (2004), "The management of financial disclosure on corporate websites: a conceptual model”, Canadian Accounting Perspectives, Vol. 3 No. 2, pp. 235-59.

Wallace, R.S.O., Nasser, K. and Mora, A. (1994), "The relationship between the comprehensive of corporate annual reports and firm characteristics in Spain”, Accounting \& Business Research, Vol. 25 No. 97, pp. 41-53.

Watson, A., Shrives, P. and Marston, C. (2002), "Voluntary disclosure of accounting ratios in the UK”, British Accounting Review, Vol. 34 No. 4, pp. 289-313.

Willis, M., Tesnière, B. and Jones, A. (2003), "Corporate communications for the 21st century", a white paper discussing the impact of internet technologies on business reporting, PricewaterhouseCoopers, New York, NY, available at: www.pwcglobal.com/xbrl

Xiao, J.Z., Dyson, R.J. and Powell, P.L. (1996), "The impact of information technology on corporate financial reporting: a contingency perspective", British Accounting Review, Vol. 28 No. 3, pp. 203-27.

Xiao, J.Z., Yang, H. and Chow, C.W. (2004), "The determinants and characteristics of voluntary internet-based disclosures by listed Chinese companies”, Journal of Accounting \& Public Policy, Vol. 23 No. 3, pp. 191-225.

Zhang, T., He, Y. and Gao, S.S. (2007), “The determinants of internet financial reporting: empirical evidence from China”, paper presented at the BAA Annual Conference, Royal Holloway, University of London, London.

\section{Appendix. Disclosure index \\ Disclosure content items}

(1) English web sites.

(2) Arabic web sites.

(3) Quarterly report of current year.

(4) Quarterly reports of past years.

(5) Semi-annual report of current year.

(6) Semi-annual report of past years.

(7) Audit review report.

(8) Current year financial statements.

(9) Historical financial statements.

(10) Current year annual reports.

(11) Annual reports of past years.

(12) Excerpts of financial reports or statements.

(13) Letter from the chairman or CEO.

(14) Chairman or CEO's signature or printed name.

(15) Auditor's report of current year.

(16) Auditor's report of past years.

(17) Auditor's signature. 
(18) Auditor's name printed.

(19) Note on language translation and audit.

(20) Current year balance sheet.

(21) Balance sheet of past years.

(22) Summarized balance sheet.

(23) Current year income statement.

(24) Income statement of past years.

(25) Summarized income statements.

(26) Current year statement of cash flow.

(27) Past years' statements of cash flow.

(28) Summarized statement of cash flow.

(29) Appropriation statement (statement of proposed dividend).

(30) Statement of changes in stockholders' equity.

(31) Notes to financial statements of current year.

(32) Notes to financial statements of past years.

(33) Usage of comparative figures.

(34) Summary of financial data over a period of at least three years.

(35) Segmental reporting by line of business (revenue).

(36) Segmental reporting by sector (revenue).

(37) GAAP basis in the year reported.

(38) Disclosure of risk or risk management.

(39) Earnings per share.

(40) Other ratios.

(41) Background or history of the organisation.

(42) Forward looking information.

(43) Supplement or amendment to current year annual report.

(44) Past year material events.

(45) Current year material events.

(46) Corporate governance.

(47) Press releases.

(48) Financial calendar.

(49) Top ten stockholders in current year.

(50) List of BOD names.

(51) List of key executives names and phone number.

(52) Historical share prices.

(53) Current share prices.

(54) Share price performance in relation to stock market index.

(55) Services or products provided.

(56) Sales of key products.

(57) Market share of key products.
Corporate internet reporting 
MAJ

25,2

202

Presentation format items

(1) Contact us.

(2) E-mail.

(3) Postal address.

(4) Telephone number.

(5) One click to get to investor relations or financial information.

(6) E-mail to investor relations or financial control manager.

(7) Investor relations phone number.

(8) Investor relations postal address.

(9) Frequently asked questions.

(10) Internal search engines.

(11) Link to the stock exchange web sites.

(12) Link to securities companies' web sites.

(13) Link to parent or subsidiary.

(14) Table of content/sitemap.

(15) Hyperlinks inside the annual report.

(16) Powerpoint or presentation of financial data.

(17) Financial data in excel.

(18) Financial data in PDF format.

(19) Financial data in HTML.

(20) Financial data in Word.

(21) Graphics or diagrams.

(22) Pull-down menu.

(23) Click-over menu.

(24) Financial information found in more than one place.

(25) Conference calls.

(26) Ratings.

(27) Disclaimer.

(28) Contact to the webmaster.

(29) Use of frames.

(30) One click to get to press releases or news.

(31) Clear boundaries for annual reports.

\section{Corresponding author}

Doaa Aly can be contacted at: daly@glos.ac.uk

To purchase reprints of this article please e-mail: reprints@emeraldinsight.com Or visit our web site for further details: www.emeraldinsight.com/reprints 